\title{
COMMUNITY ATTITUDES TO MENTAL ILLNESS IN EDINBURGH
}

\author{
BY \\ UNA MACLEAN, Ph.D. \\ Department of Social Medicine, University of Edinburgh
}

Although the importance of considering community attitudes in relation to mental illness has often been remarked (Lewis, 1956-57; W.H.O., 1959; Royal Commission 1957), there appears to have been little systematic research on the subject in Great Britain* apart from the work of Rawnsley $(1965,1967)$ and Belson in London (1957a). In the course of a cross-cultural survey involving America and Hawaii, Askenasy and Zavalloni (1963) did include the views of employees and workers in the Oxford area but, since their attention was focused upon a particular industrial sector of society, their observations fall into the more numerous class of reports on the attitudes to mental illness and towards mental patients held by certain special groups in the community. Groups which have been studied in Britain include psychiatrists (Kreitman, 1962), general practitioners (Mowbray, Blair, Jubb, and Clarke, 1961; Rawnsley and Loudon, 1962a, 1962b; medical students (Walton, Drewery, and Carstairs, 1963), the staff of mental hospitals (Carstairs and Heron, 1957), and the relatives of mental patients (Rawnsley, Loudon, and Miles, 1962; Folkard, 1960; Folkard, Mandelbrote, and Monro, 1962; Mills, 1962; Patten 1961, 1963).

A knowledge of the prevailing level of opinions and attitudes in this area, although it may go some way towards resolving the debate over different medical and sociological models of mental disorder (Erikson, 1957; Goffman, 1959, 1963; Scheff, 1966; Siegler and Osmond, 1966), is not simply of theoretical interest. In the first place, the successful implementation of the humane provisions of the 1959 Mental Health Act, with its emphasis on informal admission procedures and the anticipated maintenance of many ex-mental patients in the commu-

*There is an extensive American literature on the subject. The summary of Halpert (1963) is useful but does not extend to the recent period during which important work on sickness behaviour has been
developing (Phillips, 1963, 1964, 1965; Mechanic and Volkart, 1960 1961; Mechanic, 1962, 1966). nity, clearly continues to depend in part upon the response of society to the new provision and new treatments and to peoples' awareness of the existing arrangements. Secondly, community attitudes carry implications for the epidemiology of mental illness, $\uparrow$ since the number and types of mental disorders diagnosed as such by psychiatrists is not only closely related to the definitions of illness held by those persons who are presently to be called patients, but also to the definitions and attitudes of their relatives, their friends, and all the agents controlling deviant behaviour in society. Finally, if it should be thought desirable or practicable to embark upon programmes of mental health education to modify public attitudes and opinions regarding this topic, some knowledge of the existing level of information in the target population would seen to be a necessary prerequisite for any realistic propaganda exercise.

The following paper will describe the method and some aspects of the results of a survey carried out in 1966 among a random sample of the adult Edinburgh population into the level of local information regarding the causes, course, and prospects of cure of mental illness and into existing attitudes towards the mentally ill and ex-mental patients.

\section{MethoD}

A random sample of 500 persons over the age of 21 years was picked from the electoral roll $\neq$, using the 830 Census Enumeration Districts for the City of Edinburgh as first stage units and the streets within 25 randomly selected districts as second stage units. A team of eight interviewers, women with previous experience in market and social research, were

That this process is already causing concern among specialists can be seen by the questions they have lately begun to pose, such as "Who ought to see a psychiatrist?" (Kessel, 1962) and "Can we afford "Wental health?' (Forrest, 1967).

$\ddagger$ Excluding Service and $Y$ voters. 
recruited and specially trained in the purpose and method of the survey and were then randomly issued with lists of adult electors.

The instrument consisted of a structured schedule, refined and developed as a result of two pilot studies and with the co-operation of M.R.C. unit members and standardized in some of its sections by comparison with the views of twelve Scottish University teachers of psychiatry.

The questionnaire included the usual demographic variables of age, sex, class, and education; measures of first hand personal experience of mental illness and the mentally ill and of information acquired through the mass media; the twelve-item form of the Maudsley Personality Inventory (Eysenck, 1958); a measure of respondents' regard for what Phillips (1965) had called "the norm of self reliance"; and a final section on personal "recipes for avoiding mental illness". The central portion of the questionnaire consisted of 47 statements of attitudes and opinion.* Certain of the attitude statements were grouped to comprise a "Sympathy Scale" and a "Social Distance" scale.

The construction of these scales and the results obtained with them are described elsewhere (Maclean, 1967). An "attitude" was arbitrarily taken, after Sprott (1952), to be a statement more emotionally charged than an "opinion". The attitude statements were intended to elicit respondents' feelings about the mentally ill and ex-mental patients. whilst the opinion statements related to matters of information or belief regarding the causes, course, and prospects of cure of mental illness. The statements used were culled from a variety of sources (Star, 1950; Nunnally, 1961; Belson, 1957b) and had been modified to reduce possible ambiguity.

The phrase "mental illness" was employed throughout the schedule. No definition of the term was demanded from respondents, but they were required at the outset to rank "mental illness", "insanity", and "nervous breakdown" in order of seriousness or dreadfulness, along with five other diagnostic labels for "physical" illnesses, including cancer.

The opinion and attitude statements were administered on individual cards, always in the same sequence, and respondents were instructed to "post" each of the cards in turn into one of five possible labelled compartments of a specially designed box, according to the extent of their agreement or disagreement with the printed sentiments.

*Appended opposite.
The method of administration, a development of that used by Ingham (1965), was intended to mini- 3 mize interviewer-respondent interaction over sensi- ? tive attitudinal matters. Transfer of the results of this portion of the schedule to the actual questionnaire form was the later responsibility of the interviewer. In other respects the encounter followed the conventional pattern of a structured interview, except for the M.P.I. test, where the respondent personally completed the score sheet.

The investigation took place during the months of June and July, 1966. At least three calls at the address of each designated respondent were necessary before the interviewer relinquished the search, and further calls were made at the address of half those who had been out after three calls, and on all those said to have been initially on holiday.

\section{Results}

446 persons were available for interview at their stated addresses at the time of the survey. Most of those missing had moved, leaving no trace. If, following the example of Cartwright, Martin, and Thomson (1959) in their Edinburgh survey of smoking habits, persons who had died or had left their specified address are excluded, the 373 intero views actually completed represent a success rate of 83.6 per cent. The refusal rate was $7 \cdot 4$ per cent.

Comparing the age-sex distribution of the survey sample with the 1961 Census of Edinburgh, the main deficiencies among the 167 males were in those under 35 years of age, men away at work by day and often out in the evenings as well. The sample of 206 females was short of women under 25 years, whereas there was a relatively high proportion of women from age 25 to age 40 , more accessible because of domestic duties. Finally, there was a shortage of women over 65 . The male:female ratio of the Edinburgh sample was $1: 1 \cdot 23$, the corresponding ratio for the Census being $1: 1 \cdot 24$.

Personal experience of the mentally ill was reported by more than half of the sample ( 55 per cent.) and 6 per cent. volunteered the information that they themselves had once been mentally ill. 41 per cent. of respondents had visited mental hospitals, mainly in the Edinburgh area and within the last 10 years. Recently acquired information on the subject of mental illness was reported by nearly 60 per cent. of the sample, television having been the chief source of data.

The sample belonged predominantly to Social Class III (54 per cent.); one-quarter had been edu- 
cated beyond secondary modern standard; onethird never attended church.

The respondents' mean score on the neuroticism scale of the short M.P.I. was $5 \cdot 57$ (S.D. 3.74), and the mean extraversion score was 7.01 (S.D. 3.11).

Cancer headed the list of dreaded illnesses for the members of the sample, taking priority over psychiatric disorders of any kind. The term "mental illness" was ranked by most respondents between "insanity" and "nervous breakdown".

\section{Responses to Opinion and Attitude Statements}

In reporting on the responses to opinion and attitude statements, groups of related statements will be dealt with together and, where appropriate, comparisons will be made with the results obtained in 1956 by Belson in his London survey among B.B.C. audiences (Belson, 1957a). The list of 47 statements referred to in the text is appended to this article.

The Potential Danger of the Mentally Ill.Statements 1, 12, and 41 all referred to the potentially dangerous characteristics of the mentally ill and to their association in the popular mind with violent and unpredictable behaviour.

Table I compares the attitudes of Edinburgh and London people in relation to a set of somewhat similar propositions on the theme of violence. There was close agreement in the proportion, namely one-third, who would see in the mentally ill a source of possible danger to the community.

TABLE I

EDINBURGH AND LONDON VIEWS ON POTENTIAL DANGERS OF MENTAL ILLNESS

\begin{tabular}{|c|c|c|c|c|}
\hline \multirow[b]{2}{*}{ Sample } & \multirow[b]{2}{*}{ Opinion } & \multicolumn{3}{|c|}{ Percentages } \\
\hline & & Agree & $\begin{array}{c}\text { No } \\
\text { opinion }\end{array}$ & $\begin{array}{l}\text { Dis- } \\
\text { agree }\end{array}$ \\
\hline \multirow{3}{*}{$\begin{array}{l}\text { Edinburgh } \\
1966\end{array}$} & $\begin{array}{l}\text { "The mentally ill are } \\
\text { dangerous" (No. 1) }\end{array}$ & 33 & 16 & 51 \\
\hline & $\begin{array}{l}\text { "Mentally ill people are } \\
\text { ruled more by their } \\
\text { emotions than normal } \\
\text { people are" (No. 12) }\end{array}$ & 75 & 18 & 7 \\
\hline & $\begin{array}{l}\text { "The mentally ill are un- } \\
\text { reliable, you never } \\
\text { know what they will } \\
\text { do next" (No. 41) }\end{array}$ & 57 & 21 & 22 \\
\hline \multirow{3}{*}{$\begin{array}{c}\text { London } \\
1956\end{array}$} & $\begin{array}{l}\text { "You never know what } \\
\text { they are planning and } \\
\text { it may be harmful" }\end{array}$ & 33 & 27 & 40 \\
\hline & $\begin{array}{l}\text { "To tell you the truth, } \\
\text { they scare me a bit" }\end{array}$ & 25 & 18 & 57 \\
\hline & $\begin{array}{l}\text { "They need very careful } \\
\text { handling", }\end{array}$ & 83 & 7 & 10 \\
\hline
\end{tabular}

The same suggestion was more gently hinted at in statements to do with unpredictability, emotionalism, and the "need for careful handling". Such anxietyprovoking statements drew admissions from many more respondents to the effect that the mentally ill made them feel uneasy and insecure. Opinion in this area clearly still carries an undertone of fear and uncertainty.

Views of Hospital Committal and its Consequences. -A series of statements all concerned with public awareness of the process of admission to hospital, retention in an institution, and the possible outcome of such procedures are considered together in Table II. The contrast between responses to Statements 2 and 7 is interesting, many more people urging immediate "hospital treatment" than recommending an "institution". The very size of the majority in favour of hospitalization raises the suspicion that custodianism is possibly masquerading in the guise of care.

TABLE II

HOSPITAL COMMITAL AND ITS CONSEOUENCES : VIEWS OF 373 EDINBURGH RESPONDENTS

\begin{tabular}{|c|c|c|c|}
\hline \multirow[b]{2}{*}{ Opinion } & \multicolumn{3}{|c|}{ Percentage } \\
\hline & Agree & $\begin{array}{l}\text { No } \\
\text { opinion }\end{array}$ & $\begin{array}{l}\text { Dis- } \\
\text { agree }\end{array}$ \\
\hline $\begin{array}{l}\text { "The mentally ill should be put away } \\
\text { in institutions" (No. 2) }\end{array}$ & 43 & 13 & 44 \\
\hline $\begin{array}{l}\text { "As soon as someone begins to show } \\
\text { signs of mental disturbance he } \\
\text { should receive hospital treatment" } \\
\text { (No. 7) }\end{array}$ & 94 & 3 & 3 \\
\hline $\begin{array}{l}\text { "Most people in mental hospitals } \\
\text { nowadays have gone in of their own } \\
\text { free will" (No. 43) }\end{array}$ & 60 & 24 & 13 \\
\hline $\begin{array}{l}\text { "Most patients in mental hospitals } \\
\text { have to be kept there against their } \\
\text { will" (No. 9) }\end{array}$ & 35 & 18 & 47 \\
\hline $\begin{array}{l}\text { "Few people who enter a mental } \\
\text { hospital ever leave it"'(No. 32) }\end{array}$ & 13 & 14 & 73 \\
\hline $\begin{array}{l}\text { "Mental patients usually settle back } \\
\text { into ordinary life again quite easily } \\
\text { when they are discharged from hos- } \\
\text { pital" (No. 29) }\end{array}$ & 52 & 23 & 25 \\
\hline $\begin{array}{l}\text { "Many of the mentally ill people who } \\
\text { seem to be better will be back for } \\
\text { more treatment later on" (No. 33) }\end{array}$ & 56 & 25 & 19 \\
\hline
\end{tabular}

Whilst voluntary admission procedures are fairly generally known, as many as $\mathbf{4 0}$ per cent. are still in ignorance or mistaken regarding current policy.

Almost half the population realize that patients inside hospital are not subject to physical restraint to keep them there. This does, however, leave over half the Edinburgh respondents still dubious on this score or believing in the continued operation of restrictions.

In Edinburgh mental hospitals are evidently not now regarded as final depositories for the deviant, and most people are aware that patients do have the 
prospect of release. But the total effect of a period of stay in a mental institution is none too favourably regarded. Only just over half the sample anticipate for patients an easy transition back to "ordinary life", and more than half take the sober view that further spells in hospital are in prospect for anyone who has once been inside.

This lends some support to the views of those sociologists (Scheff, 1966; Goffman, 1961) who have warned of the lasting consequence of labelling someone mentally ill. It has by no means finally been demonstrated, however, whether the mentally ill tend to have frequent encounters with therapy because of or in spite of the prevailing attitudes of the members of their immediate group(Freeman and Simmons, 1958). And the fact that improvements in treatment are likely to influence and modify public attitudes toward hospital treatment makes the task of unravelling the individual effects of these two factors in a changing situation extremely difficult.

Explicit Sympathy for the Mentally Ill.-The two statements, No. 3, "People who are mentally ill are to be pitied", and No. 14, "What the mentally ill need more than anything else is to have people show them sympathy", are both straightforward invitations to benevolence, and it was scarcely to be expected that many people would express outright disagreement. Most Edinburgh people were indeed overtly sympathetic in these terms, and Belson had similarly found 89 per cent. of the London viewers agreeing with the statement, "I feel sorry for the mentally ill", and 68 per cent. saying, "I pity them".

However, some respondents in the pilot study specifically stated that, in their opinion, to show "pity" or "too much sympathy" might simply make the mentally ill still more sorry for themselves and so impede their recovery. A heartily reassuring manner, along "pull yourself together" lines, is probably fairly widespread and may in fact have the effect of delaying recourse to medical advice. Until the connexion between early consultation (at any medical level) and subsequent increased chances of "cure" can be established, such delaying or denying tactics could well be taken as an indication of welcome community tolerance for minor illness.

The Contagion of Mental Illness.-Statement 4 asserts, "Close association with people who are mentally ill is liable to make a normal person break down". Over 40 per cent. of people appear to feel some apprehension in this regard. The belief is not an unreasonable one, in view of the constant strain of living with a seriously disturbed individual. Such reactions need to be weighed when advocating "community care", unless the medical services are geared to provide sufficient domestic support.

But agreement with this particular proposition may also be implying a degree of repugnance and revulsion regarding mental illness, as something which could directly damage and contaminate one. The company of the mentally ill may be seen to have the additional disadvantage of implicating a close associate in the stigma accompanying a diagnosis of mental illness.

Social Acceptability of the Ex-Mental Patient.Statements referring to the social acceptability of an ex-mental hospital patient were employed in the construction of a Social Distance Scale (reported elsewhere, Maclean, 1967). Since the hypothetical situations posed for respondents were very similar to those used by Belson in London, comparisons have been drawn in Table III.

TABLE III

SOCIAL ACCEPTABILITY OF EX-MENTAL PATIENTS (percentage replying)

\begin{tabular}{|c|c|c|c|c|c|c|}
\hline \multirow{2}{*}{$\begin{array}{l}\text { Role suggested for } \\
\text { Ex-patient }\end{array}$} & \multicolumn{3}{|c|}{ Edinburgh, 1966} & \multicolumn{3}{|c|}{ London, $1956 \Omega$} \\
\hline & Agree & $\begin{array}{c}\text { No } \\
\text { opinion }\end{array}$ & $\begin{array}{l}\text { Dis- } \\
\text { agree }\end{array}$ & Yes & $\begin{array}{l}\text { Not } \\
\text { sure }\end{array}$ & N8 \\
\hline Workmate & 77 & 11 & 12 & 92 & 6 & 2 \\
\hline Next-door neighbour & 64 & 19 & 17 & 89 & 9 & 2 \\
\hline $\begin{array}{l}\text { Important or respon- } \\
\text { sible position }\end{array}$ & 39 & 26 & 35 & 25 & 37 & 38 \\
\hline Baby-sitter & 26 & 26 & 48 & 20 & 36 & 44 \\
\hline Teacher & 26 & 27 & 37 & 20 & 36 & 44 \\
\hline $\begin{array}{l}\text { District nurse (Ed.) } \\
\text { Nursemaid (Lond.) }\end{array}$ & 50 & 26 & 24 & 20 & 36 & 44 \\
\hline $\begin{array}{l}\text { Family member } \\
\text { through marriage }\end{array}$ & 21 & 24 & 55 & 21 & 44 & 35 \\
\hline
\end{tabular}

Edinburgh people seemed less prepared to countenance distant relationships with ex-patients than 0 did the Londoners. But as far as contemplating closer roles was concerned, such as teacher, baby- o sitter, or family member, there was little difference between the two groups of respondents.

Perceived Causes of Mental Illness.-Statements relating to possible causes of mental illness have $\mathrm{\omega}$ been ranged in Table IV according to the percentage $\widetilde{T}$ of respondents who agreed with the suggestions put $\varrho$ forward. The statements have been considerably $\mathbb{\Phi}$ abbreviated but can be consulted in their complete? form in the appended list. 
TABLE IV

SOME POPULAR OPINIONS ON THE CAUSE OF MENTAL ILLNESS, EDINBURGH, 1966

\begin{tabular}{l|l}
\hline \multicolumn{1}{c|}{ Cause } & Percentage Agreeing \\
\hline Job worries (No. 22) & 89 \\
Overwork (No. 23) & 82 \\
Stress and strain of present-day living (No. 20) & 80 \\
Money worries (No. 26) & 74 \\
Neglect in childhood (No. 24) & 70 \\
Menopause (No. 44) & 65 \\
Unhappy home life (No. 19) & 65 \\
Lack of moral strength (No. 27) & 42 \\
Gloomy thoughts (No. 25) & 39 \\
Sexual overindulgence (No. 28) & 38 \\
Accidents or illness (No. 17) & 37 \\
Drink (No. 18) & 30 \\
Masturbation (No. 46) & 15 \\
\hline
\end{tabular}

Ordinary people tend to look outside, to the particular circumstances in which their lives are led, to explain the occurrence of mental illness, blaming "strains" which they perceive as actually existing in the external environment rather than within their own personalities. This sample was predominantly composed of members of Social Class III and below, with jobs which may indeed have been more precarious than those of the professional classes and with perennial financial problems. In the face of such circumstances many people advocate a determined attitude of enforced cheerfulness, on the assumption that mood can be changed at will. So the effect of a bad life situation is not seen as leading inevitably to mental breakdown but to lie, partially at least, within the power of the individual to control. Many of the respondents' "Recipes for Avoiding Mental Illness" illustrated this reasoning process in more detail.

Belson had also found 83 per cent. of his sample blaming "strain" and "worry" of one sort or another. A much smaller proportion of the London group (48 per cent.) than of the Edinburgh sample specifically indicated family trouble, and only 33 per cent. of Belson's sample made reference to past surroundings, such as ill-treatment as a child. The Edinburgh respondents seemed to be placing much more emphasis on the effect upon children of feeling they are "not wanted", but whether this is evidence of the spread of the gospel of Bowlby (1953), or whether it simply reflects a long-standing local belief cannot be determined. The menopause ranks high on the Edinburgh list of causes of mental ill- ness, wheras it was only referred to (along with puerperal disturbances) by 13 per cent. of Londoners. But the remaining causes, such as a bad way of life (as evinced by drink and "moral weakness"), and specific physical causes, such as accidents or illness, came low among the baleful influences cited in both Edinburgh and London. It is noteworthy that, although only 15 per cent. of the Edinburgh sample thought that masturbation could cause mental illness, nearly 40 per cent. had no opinion about it and the same proportion regarded "sexual overindulgence" as dangerous.

The tendency to blame symptoms upon circumstances and to excuse "bad" behaviour because of background or personality is deplored by some practising clinicians. Forrest (1967), when posing the question "Can we afford mental health?", proposed a return to a greatly restricted sphere of therapeutic concern. Such a panic retreat on the part of psychiatrists would seem unfortunate at a time when their part in the system of medical care is being increasingly accepted by the public.

Moreover, the prevailing popular view as expressed in this survey finds support in the observation of many other psychiatrists regarding the importance of social factors in illness. Even if it may be the prior personality structure of people subjected to specific environmental pressures which ultimately determines their liability to breakdown, the provocative effect of social circumstances cannot for that reason be disregarded in a multifactorial situation.

Perceived Public Tolerance.-Statement 42, "People nowadays are sufficiently tolerant towards the mentally ill" evoked what appeared to be a degree of complacency regarding the current situation. Possibly the 60 per cent. who agreed were thinking of the contrast between the present climate of opinion and that which obtained in earlier times.

Personal Dread of Mental Illness.-The statement (No. 31) expressing horror at the idea of developing a mental illness was supported by over 70 per cent. of respondents, who corroborated the anxious feelings about psychiatric disability which had been expressed in the rank ordering of diagnostic terms in the beginning of the interview.

Personal Characteristics of the Mentally Ill. These were touched upon in Statements $8,10,35$, 36,38 , and 39. 71 per cent. of the Edinburgh group agreed that the mentally ill "seem to live in a different world", although the majority would not go to the length of classifying them as scarcely human. Opinion divides fairly evenly on a statement of 
patients' supposed strangeness ("When a person becomes mentally ill, it's just like losing them altogether") and on their personal untidiness, but the belief that mentally ill people are likely to manifest suicidal behaviour is held by 60 per cent. of the sample. The latter response may be taken as further evidence for the continuing tendency to connect mental illness and violent behaviour.

TABLE V

RELATIONSHIP BETWEEN RESPONDENT CHARACTERISTICS AND INFORMATION OR OPINIONS ON MENTAL ILLNESS AND THE MENTALLY ILL

\begin{tabular}{|c|c|c|}
\hline $\begin{array}{l}\text { Respondent } \\
\text { Characteristic }\end{array}$ & Subject Matter & Significance* \\
\hline $\begin{array}{l}\text { Reported personal } \\
\text { experience of the } \\
\text { mentally ill }\end{array}$ & $\begin{array}{l}\text { Potential danger (No. 1) } \\
\text { Potential unpredictability (No. } \\
\text { 41) } \\
\text { Advisability of immediate } \\
\text { hospital treatment (No. 7) } \\
\text { Knowledge of voluntary } \\
\text { admission (No. 43) } \\
\text { Necessity for enforced custody } \\
\text { (No. 9) eventual } \\
\text { Likelihood of ed evere (No. 32) } \\
\text { discharge }\end{array}$ & $\begin{array}{l}\text { n.s. } \\
\text { n.s. } \\
\text { n.s. } \\
\text { sig. } \\
\text { n.s. } \\
\text { n.s. }\end{array}$ \\
\hline $\begin{array}{l}\text { Reported recent } \\
\text { information on } \\
\text { mental illness }\end{array}$ & $\begin{array}{l}\text { Voluntary admission (No. 43) } \\
\text { Enforced custody (No. 9) } \\
\text { Taboo topic (No. 5) }\end{array}$ & $\begin{array}{l}\text { n.s. } \\
\text { n.s. } \\
\text { n.s. }\end{array}$ \\
\hline Age (over 50) & $\begin{array}{l}\text { Potential danger (No. 1) } \\
\text { Potential unpredictability } \\
\text { (No. 41) } \\
\text { Mental illness seen as a taboo } \\
\text { topic (No. 5) } \\
\text { Sexual overindulgence seen as } \\
\text { a cause (No. 28) }\end{array}$ & $\begin{array}{c}\text { sig. } \\
\text { sig. } \\
\text { (highly) sig. } \\
\text { sig. }\end{array}$ \\
\hline Sex (Female) & $\begin{array}{l}\text { Potential danger (No. 1) } \\
\text { Mental illness not a taboo } \\
\text { topic (No. 5) } \\
\text { Sexual overindulgence not } \\
\text { seen as a cause (No. 28) } \\
\text { Ex-mental patient suitable as } \\
\text { teacher (No. 40) } \\
\text { Female ex-patient suitable as } \\
\text { baby sitter (No. 6) }\end{array}$ & $\begin{array}{l}\text { n.s. } \\
\text { (highly) sig. } \\
\text { (highly) sig. } \\
\text { n.s. } \\
\text { n.s. }\end{array}$ \\
\hline $\begin{array}{l}\text { No education } \\
\text { beyond primary } \\
\text { level }\end{array}$ & $\begin{array}{l}\text { Potential unpredictability } \\
\text { (No. 41) } \\
\text { Enforced custody (No. 9) } \\
\text { Mental illness seen as a taboo } \\
\text { topic (No. 5) } \\
\text { Sexual overindulgence seen as } \\
\text { a cause (No. 28) }\end{array}$ & $\begin{array}{c}\text { n.s. } \\
\text { n.s. } \\
\text { (highly) sig. } \\
\text { sig. }\end{array}$ \\
\hline $\begin{array}{l}\text { Endorsement of self- } \\
\text { reliance }\end{array}$ & $\begin{array}{l}\text { Lack of moral strength a cause } \\
\text { (No. 27) }\end{array}$ & sig. \\
\hline $\begin{array}{l}\text { Religious } \\
\text { affiliation }\end{array}$ & $\begin{array}{l}\text { Lack of moral strength a cause } \\
\text { (No. 27) }\end{array}$ & n.s. \\
\hline $\begin{array}{l}\text { Belief in restraint } \\
\text { within hospital } \\
\text { (No. 9) }\end{array}$ & $\begin{array}{l}\text { Likelihood of eventual dis- } \\
\text { charge (No. 32) }\end{array}$ & (highly) sig. \\
\hline
\end{tabular}

Variables afFecting Responses to Certain Atritude and Opinion Statements (Table V) These aspects of the analysis tended to bear out the findings of most American investigators to the effect that age and education influence opinions in this field, those who are old and ill-taught being furthest from "enlightenment" in whatever terms it happens to be measured.

It will be seen that personal experience did not $\stackrel{\mathbb{D}}{\propto}$ significantly reduce the tendency to regard the mentally ill as dangerous nor did experience modify the inclination to consider such individuals as unpredictable and unreliable.

Personal experience was significantly related to knowledge about the prevalence of voluntary admission procedures and was almost significantly associated with correct information regarding current conditions of custody within hospitals.

The older the respondents the more inclined were of they to view the mentally ill with dread and suspicion, 을 to dislike discussion of the whole topic of mental illness, and to cite sexual overindulgence as a cause of affliction.

Education did not significantly reduce attitudes regarding the unpredictable behaviour of the mentally ill.

Views on restraint within mental hospitals were highly significantly related to the belief that in carceration would probably prove permanent for $\vec{r}^{+}$ most patients.

\section{CONCLUSIONS}

The results reported here show that in 1966 the Edinburgh public were generally familiar with the topic and prepared to discuss it frankly. It was held in less horror than malignant disease. Many traces of old stereotypes of mental illness still remained, however, and neither education nor personal experience of mental illness modified a persistent tendency to regard mental patients as potentially unpredictable and violent. There was also some feeling against too close an association with the mentally ill, possibly betraying a fear of contagion from a still dreaded affliction. But the presence of ex-patients would be generally acceptable in roles not involving too intimate contact.

People over 50 years of age were more inclined to view the mentally ill with suspicion and alarm, to dislike discussion of it, and to implicate sexual behaviour in its causation. Education, on the other hand, made people more ready to discuss the subject and less likely to blame sex.

Provided psychiatrists agree upon the value and form of hospital treatments, there would seem to be room for improvement in the general level of public 
information regarding current conditions of admission to mental hospitals and custody within them.

The Edinburgh public perceive the predominant causes of mental illness as "stresses and strains" in the external environment, but they incline towards optimism and to the belief that will-power can triumph over difficult circumstances.

The changing public view of mental illness, as some of the elderly and ill-educated are replaced by a more enlightened generation, could pose increasingly serious problems for practising psychiatrists, trying to cope with a growing and varied clientele.

The study which is partially reported above was carried out with the aid of a generous grant from the Medical Research Council. The advice and assistance of Prof. G. M. Carstairs and Dr Graham Foulds were invaluable.

\section{REFERENCES}

Askenasy, A. R., and Zavalloni, M. (1963). "Attitudes towards Mental Illness: A Cross-cultural Study", World Federation for Mental Health, U.S. Committee, Inc., New York.

Belson, W. A. (1957a). Ment. Hlth, 16, 95 (The ideas of the television public about mental illness).

- (1957b). "The Hurt Mind: An Enquiry into Some of the Effects of the Television Series, 'The Hurt Mind",. Audience Research Deaprtment, B.B.C. (for limited circulation).

BowlBY, J. (1953). "Child Care and the Growth of Love'. Penguin Books, Middlesex.

Carstairs, G. M., and Heron, A. (1957). "The Social Environment of Mental Hospital Patients: A Measure of Staff Attitudes", in "The Patient and the Mental Hospital", ed. M. Greenblatt, D. J. Levinson, and R. H. Williams. Free Press, Glencoe, Illinois.

Cartwright, A., Martin, F. M., and Thomson, J. G. (1959). Lancet, 2, 725 (Distribution and development of smoking habits).

ERIKSON, K. T. (1957). Psychiatry, 20, 263 (Patient role and social uncertainty, the dilemma of the mentally ill).

EySENCK, H. J. (1958). J. appl. Psychol., 42, 14 (A short questionnaire for the measurement of two dimensions of personality).

FolKARD, S. (1960. Brit. J. prev. soc. Med., 14, 23 (Comparative study of the attitudes to rehabilitation of psychiatric patients).

- MANDElbrote, B., and Monro, M. (1962). Ibid., 16, 69 (Personal problems associated with mental health and mental illness).

ForRest, A. D. (1967). Scot. med. J., 12, 129 (Can we afford mental health?).

Freeman, Howard, and Simmons, O. G. (1958). Amer. sociol. Rev., 23, 147 (Mental patients in the community; family settings and performance levels).

Goffman, E. (1959). "The Moral Career of the Mental Patient", in "The Presentation of the Self in Everyday Life". Anchor Books, Doubleday, New York. (1961). "Asylums"' Doubleday, New York.

- (1963). "Stigma". Spectrum Books, Prentice Hall, Englewood Cliffs, N.J.

HALPERT, H. P. (1963). "Public Opinions and Attitudes about Mental Health'. Public Health Services Publi- cation No. 1045, U.S. Department of Health, Education and Welfare, Washington, D.C.

Ingham, J. G. (1965). Brit. J. soc. clin. Psychol., 4, 131 (A method of observing symptoms and attitudes).

KeSSEL, W. I. N. (1963). Lancet, 1, 1092 (Who ought to see a psychiatrist?).

Kreitman, N. (1962). J. ment. Sci., 108, 317 (Psychiatric orientation: a study of attitudes among psychiatrists).

LEWIS, A. (1956). "Social Psychiatry" in "Lectures on the Scientific Bases of Medicine", vol. 5, Athlone Press, London.

MACLEAN, C. M. U. (1967). "The Determination of Community Attitudes to Mental Illness", unpublished Ph.D. Thesis, University of Edinburgh.

Mechanic, D. (1962). J. chron. Dis., 15, 189 (The concept of illness behaviour).

(1966). Soc. Psychiat., 1, 11 (Response factors in illness: the study of illness behaviour).

- and VolkaRT, E. H. (1960). J. Hith hum. Behav., 1, 86 (Illness behaviour and medical diagnoses).

1, (1961). Amer. sociol. Rev., 26, 51 (Stress, illness behaviour and the sick role).

Mental Health Act, 1959. H.M.S.O., London.

MiLLs, E. (1962). "Living with Mental Illness: A Study in East London". Routledge and Keegan Paul, London.

Mowbray, R. M., Blair, W., Jubb, L. G., and Clarke, A. (1961). Scot. med. J., 6, 314 (The general practitioner's attitude to psychiatry).

Nunally, J., JR. (1961). "Popular Conceptions of Mental Health". Holt, Reinhart and Winston, New York.

PatTen, P. (1961). "Sociological Perspectives on Psychiatric Problems". Paper read to the Royal MedicoPsychological Association in July, 1961. Mimeographed copy.

(1963). "Professional and Lay Concepts of Psychiatric Illness". Paper read to the Royal Medico-Psychological Society in October, 1963. Mimeographed copy).

Phillips, D. L. (1963). Amer. sociol. Rev., 28, 963 (Rejection: a possible consequence of seeking help for mental disorders).

(1964). Ibid., 29, 679 (Rejection of the mentally ill; the influence of behaviour and sex).

(1965). Soc. Forces, 43, 555 (Self-reliance and the inclination to adopt the sick role).

R AWNSLEY, K. (1965). Postgrad. med. J., 41, 401 (Studies of social attitudes and values in relation to psychiatric epidemiology).

(1967). Personal communications.

and Loudon, J. B. (1962a). "The Attitudes of General Practitioners to Psychiatry". Sociological Review Monograph, No. 5, University of Keele.

- (1962b). Brit. J. prev. soc. Med., 16, 174 (Factors influencing the referral of patients to psychiatrists by general pactitioners.

C, and MILES, H. L. (1962). Ibid., 16, 1. (Attitudes of relatives to patients in mental hospitals).

Registrar General for Scotland (1965). "Census (Scotland) 1961". H.M.S.O., Edinburgh

Royal Commission on the Law relating to Mental Illness and Mental Deficiency (1957). Cmnd. 169, H.M.S.O., London.

ScHEFF, T. J. (1966). "Being Mentally Ill: A Sociological Theory". Wiedenfeld and Nicolson, London.

Siegler, M., and Osmond, H. (1966). Brit. J. Psychiat., 112, 1193 (Models of madness).

SPROTT, W. J. H. (1952). “Social Psychology”. Methuen, London. 
STAR, S. (1950). "Popular Thinking in the Field of Mental Health". Survey No. 272, University of Chicago Press.

Walton, H. J., Drewery, J., and Carstairs, G. M. (1963). Brit. med. J., 2, 588 (Interest of graduating medical students in social and emotional aspects of illness).

W.H.O. (1960). Technical Report on the Epidemiology of Mental Disorders, No. 185, Geneva.

\section{APPENDIX}

\section{Opinion and Attitude Statements}

1. The mentally ill are dangerous.

2. The mentally ill should be put away in institutions.

3. People who have become mentally ill are to be pitied.

4. Close association with people who are mentally ill is liable to make a normal person break down.

5. Mental illness is something it is best not to talk about

6. Most women who were once patients in a mental hospital could be trusted as baby sitters.

7. As soon as someone begins to show signs of mental disturbance they should receive hospital treatment.

8. Mentally ill people seem to live in a different world from the rest of us.

9. Most patients in mental hospitals still have to be kept there against their will.

10. Sometimes it's difficult to think of the mentally ill as ordinary human beings.

11. I would be willing for a member of my family to marry someone who had once been a mental hospital patient.

12. Mentally ill people are ruled more by their emotions than normal people are.

13. People who are mentally ill ought not to be allowed to mix with ordinary people.

14. What the mentally ill need more than anything is to have people show them sympathy.

15. A former mental patient could be trusted in a responsible position, as a lawyer, for example.

16. Rest won't prevent mental disorders.

17. It is generally accidents or illnesses that bring on mental illness.

18. Drink is one of the main causes of mental illness.

19. An unhappy home life is one of the main causes of mental illness.

20. Much mental illness is the result of the strain and stress of present-day living.
21. A change of climate seldom helps a developing mental illness.

22. Job worries can bring on mental illness.

23. Overwork is a big cause of mental illness.

24. Children who are made to feel they are not wanted may develop mental illness when they grow up.

25. Mental illness can be avoided by avoiding gloomy thoughts.

26. Money matters are a big cause of mental illness.

27. One of the main causes of mental illness is lack of $\vec{\nabla}$ moral strength.

28. Sexual over-indulgence will end for some people in mental illness.

29. Mental patients usually settle back into ordinary life again quite easily when they are discharged from hospital.

30. Mental illness can often be helped by a holiday or change of scene.

31. To develop a mental illness is one of the worst things that could happen to anyone.

32. Few people who enter a mental hospital ever leave it. 33. Many of the mentally ill people who seem to be better will be back for more treatment later on.

34. I would be willing to have a former mental patiens $\vec{\varphi}$ living next door.

35 . The eyes of the mentally ill are glassy.

36. When a person becomes mentally ill it's just like losing them altogether.

37. I would be willing to work in a job alongside a former mental patient.

38. People who are mentally ill are liable to commit suicide.

39. The mentally ill don't care about their personal appearance.

40. I would let a former mental patient teach my children.

41. The mentally ill are unreliable, you never know what they will do next.

42. People nowadays are sufficiently tolerant towards the mentally ill.

43. Most patients in mental hospitals nowadays have gone in of their own free will.

44. Women at the change of life are very liable to become mentally ill.

45. A district nurse who had been a mental hospital patient for a time could return to her job afterwards.

46. Sexual self-abuse may cause some young people to become mentally ill.

47. I think that in general people should be expected to handle their own problems. 